\title{
Redefining the system of higher education in Ukraine within the context of the internationalization process: practical rationale
}

\author{
I. V. Myhovych \\ State Institution Luhansk Taras Shevchenko National University, Starobilsk, Ukraine \\ Corresponding author. E-mail: irina.migovich@gmail.com
}

Paper received 19.05.18; Accepted for publication 27.05.18.

https://doi.org/10.31174/SEND-PP2018-170VI70-08

\begin{abstract}
The article is devoted to the investigation of the process of internationalization within the context of higher education. Internationalization is viewed as a reaction to the global transformation processes, as well as a unique possibility for Ukrainian higher education system to ensure its integrated transformation according to European and world trends. Based on the research on the theory of internationalization, international education, overseas recruitment and staff mobility, issues of quality and management in higher education a number of practical rationales for internationalization of higher education applicable within the context of Ukrainian higher education system have been outlined. Based on the rationales educational outcomes of internationalization in Ukrainian higher education have been substantiated.
\end{abstract}

Keywords: the process of internationalization, global higher education system, Ukrainian system of higher education, rationales for internationalization.

Introduction. One of the key features of the modern world is its extraordinary dynamism, the complexity and increasing interdependence of all the transformational processes that are currently taking place. There is an increased need to strengthen partnerships and coordinate actions at the national, regional and international levels in order to ensure the quality and well-being of higher education systems worldwide. As a response to this need for an integrated transformation of higher education (HE) the process of internationalization has come in view.

The emergence of internationalization is generally connected with the increased political, socio-economic, cultural and ideological homogeneity across countries based on increasing digitalization of the world, accelerating cross-border financial flows and integration of economic activity, accelerating migration, blurring of national boundaries in favor of free cross-border movement and increasing use of common currencies and languages across different nations. Thus, internationalization is the response not only to the needs of $\mathrm{HE}$, but also to the needs of international economic, social, political and cultural integration, which is growing in the face of globalization.

International cooperation is currently been considered as one of the main indicators of the definition of quality in the field of education and science and, at the same time, one of the main tools for its maintenance and enhancement. Therefore, almost all higher education institutions (HEIs) around the world are engaged in international activities and seek to expand them. Internationalization thus has ceased to be casual or specialized, and has become a more centralized, well-organized, and thoughtful component of institutional work [12, p. 45]. According to F. Maringe, over the years it has developed to become the focus of activities by leading HEIs of the world and regulatory authorities at the national and global levels [9]. At the same time in Ukrainian HE the process of internationalization remains to be quite marginal and fragmented involving mainly small-scale student and staff exchanges.

Brief review of publications on the topic. Internationalization of $\mathrm{HE}$ has been investigated by $\mathrm{N}$. Avshenyuk, N. Bidyuk, T. Desyatova, N. Zhuravskaya, I. Zadorozhna, T. Klyuchkovich, N. Lavritschenko, M.
Leschenko, A. Parinova, G. Rzhevska, A Sbravieva, J. Ainer, M. Bartell, L. K. Childress, J. L. Davies, J. Knight, M. van der Wende, W. de Winter, H. de Wit, D. Van Damme, J, Taylor, J. D. Toma, D. Walters \& T. Adams, L. Wilson.

The meaning of globalization and internationalization in HE has been analyzed by F. Maringe. N. Foskett has investigated the strategic challenges of internationalization within the context of global markets, national challenges and local strategies. J. Taylor has studied the management of internationalization in HE. Eva Egron-Polak has viewed the process of internationalization as a gateway to a new inclusive global HE space, while Berndt Waechter has looked at this process within the context of student mobility. The future of this process in AsiaPacific region has been outlined by A. Ruby. All the works mentioned above have presented different approaches to this process, outlined its history, impact on world affairs and other facets of human development and endeavor. However, the practical rationales of its implementation in Ukrainian higher education area have not yet been sufficiently investigated.

The goal. The purpose of the article is to investigate different aspects of the process of internationalization as a reaction to global transformation processes and a means for Ukrainian HE system to ensure its integrated transformation according to European and world HE standards, to offer an additional point of view on the epistemology of internationalization, as well as on practical reasons for the introduction of this process into the system of Ukrainian HE.

Materials and methods. The methodological and theoretical basis of the research is the scientific works on international education, quality and management in HE, growth of entrepreneurial education and the associated managerialism in HE, national and institutional strategies for incorporation of international education into existing curricula. The validity of the obtained results is confirmed using various generally accepted and specific methods: theoretical generalization, abstraction, dialectical analysis, comparison and systematization, system approach.

Results and discussion. It is generally acknowledged that the key factor for the emergence of the process of 
internationalization has been globalization that entails the opening up and coming together of business, trade and economic activities between nations, necessitating the need for greater homogenization of fundamental political, ideological, cultural and social aspects of life across different countries of the world. Such processes have been taking place for a long time, but have been accelerated and intensified in the past decades because of developments in technology, computers and the Internet. The impact these changes are having on universities is pro- found and, within universities, the key strategic responses to globalization have come to be known as internationalization. It is generally understood to mean the integration of an international or intercultural dimension into the tripartite mission of teaching, research and service functions of HE $[1-3 ; 6 ; 7 ; 11,13]$.

Table 1 provides a summary of definitions and perspectives of internationalization by some of the most influential writers in this field.

Table 1. Conceptualizations of internationalization in HE

\begin{tabular}{|c|c|c|}
\hline $\begin{array}{l}\text { View of Internationaliza- } \\
\text { tion }\end{array}$ & Definition / Perspective & Source \\
\hline \multirow[b]{2}{*}{$\begin{array}{l}\text { Integration of the internation- } \\
\text { al dimension }\end{array}$} & $\begin{array}{l}\text {... internationalization at the national, sector, and institutional levels is defined as } \\
\text { the process of integrating an international, intercultural, or global dimension into } \\
\text { the purpose, functions or delivery of postsecondary education. }\end{array}$ & $\begin{array}{l}\text { J. Knight, } \\
2004\end{array}$ \\
\hline & $\begin{array}{l}\text { The intentional process of integrating an international, intercultural or global } \\
\text { dimension into the purpose, functions and delivery of post-secondary education, } \\
\text { in order to enhance the quality of education and research for all students and } \\
\text { staff, and to make a meaningful contribution to society. }\end{array}$ & de Wit, 2015 \\
\hline Enhancing the quality of $\mathrm{HE}$ & $\begin{array}{l}\ldots \text { increasing focus on international educa } \\
\text { global labor market, but equally raises issue }\end{array}$ & $\begin{array}{c}\text { Van Damme, } \\
2001 \\
\end{array}$ \\
\hline $\begin{array}{l}\text { Focus on international educa- } \\
\text { tion }\end{array}$ & $\begin{array}{l}\text {... ranges from traditional study abroad programs, which allow students to learn } \\
\text { about other cultures, to providing access to HE in countries where local institu- } \\
\text { tions cannot meet the demand. Other activities stress upgrading the international } \\
\text { perspectives and skills of students, enhancing foreign language programs, and } \\
\text { providing cross-cultural understanding. }\end{array}$ & $\begin{array}{l}\text { Altbach and } \\
\text { Knight, } 2006\end{array}$ \\
\hline $\begin{array}{l}\text { Growth of enterprise, entre- } \\
\text { preneurialism and manageri- } \\
\text { alism in HE }\end{array}$ & $\begin{array}{l}\ldots \text { internationalization as crucial for universities to retain competitiveness } \\
\text { through university business models which underpin an entrepreneurial culture ... } \\
\text { universities as entirely business entities. }\end{array}$ & $\begin{array}{l}\text { Goddard, } \\
2006\end{array}$ \\
\hline $\begin{array}{l}\text { Overseas student recruitment } \\
\text { and staff mobility focus }\end{array}$ & $\begin{array}{l}\text {... flows of staff and students in both directions, strategic alliances, joint pro- } \\
\text { grammes with external institutions. }\end{array}$ & $\begin{array}{l}\text { Fielden, } \\
2008\end{array}$ \\
\hline $\begin{array}{l}\text { Partnership development in } \\
\text { HE }\end{array}$ & $\begin{array}{l}\ldots \text { a focus on the development of partnerships to reduce risk, increase competi- } \\
\text { tiveness, enhance image and broaden the knowledge base for research, enterprise } \\
\text { and education. }\end{array}$ & $\begin{array}{l}\text { Teichler, } \\
2004\end{array}$ \\
\hline
\end{tabular}

One might say that most universities operate primarily in their own national space and context, and are part of the educational system within their own country. Shaped in many ways by history and legislative / governmental acts and policies in relation to education, their key accountabilities lie within their own national boundaries. However, it is exactly the process of internationalization that is to become their gateway to a global HE system.

For Ukraine the requirements of globalization and European integration for a long time remained rather vague. This fact has influenced the processes of internationalization of HE that has never been viewed as a priority of the state educational policy. Within the implementation of Joint Declaration of the European Ministers of Education (the Bologna Declaration) provisions formal aspects related to the introduction of the system of credits and twolevel training in Ukrainian HE prevailed. However, while in European countries such implementation considered to be an instrument for ensuring large-scale student mobility, there has been no significant increase in academic mobility in Ukraine over the last decade. The requirements of globalization and eurointegration did not integrate properly into the national strategy for the development of Ukrainian HE. Although in the Law "On Higher Education" (2014) international integration of Ukrainian HE is one of the main principles state educational policy is based upon, the notions of international cooperation, international integration, internationalization have not been mentioned among the basic terms, and in the Law itself there is no mentioning of the term internationalization [8].

Insufficient attention to the issues of internationalization in Ukrainian HE system has turned into slow proceeding of the process, which is evident, if to have close look at the following data:

- the number of students taking part in mobility programs rates from 5,000 to 10,000 persons per year, which is $0,5-1,0 \%$ of the total amount of students of HEIs with the III - IV levels of accreditation (full-time study) and total amount of students of HEIs with the I - II levels of accreditation (full-time study). At the same time there is practically no participation of Ukrainian teachers and professors in mobility programs [10, p. $130-143]$.

- The percentage of involvement of researchers and university teachers in international cooperation is quite low - proportion of those who have studied or worked abroad is small and number of holders of foreign academic degrees is negligible. Ukraine continues to be the country mainly exporting staff with higher scientific qualifications abroad [14, p. 88].

- Professorial staff of Ukrainian HEIs is insufficiently represented on the world scholar arena.

- HEIs of Ukraine are practically not represented, or they have low institutional ranking, in the leading international HE rating systems.

- Low activity of national HEIs in establishing partnerships with HEIs and research institutions abroad. As the 
result, the issue of cooperation of Ukrainian HEIs with foreign leading HEIs has a non-systematic character.

Today, just as well as 25 years ago, internationalization is not perceived as an urgent need that might foster the development of Ukrainian HE. The present article is aimed to give an answer to the question "why internationalize?" in a realistic and sufficiently pragmatic way. The idea of becoming competitive on the world educational market is extremely ambitious for Ukrainian $\mathrm{HE}$ - following many researchers in the field it is perceived as a longterm challenge. At the same time the task of improving quality of Ukrainian $\mathrm{HE}$ in accordance with world and European standards through the elaboration and implementation of new international educational programs and integration of international elements and educational standards looks more realistic and urgent. As the result, the article supports the following view on the problem Ukrainian HE system should integrate global and regional dimensions into its national context with the aim to harmonize national, global, regional requirements and conditions. To fulfill this task the following practical rationales have been outlined:

1. Political rationale is connected with the need to acquire, preserve and strengthen the independence and sovereignty of the nation / state and their role in the international arena. For HEIs political stimulus finds its manifestation in the idea to strengthen autonomy of state and enhance its status on the international arena. This dimension might as well be implemented through internationalization, international cooperation and partnership.

2. Economic rationale relates to the benefits that internationalization might bring to Ukrainian state economy and HEIs. It becomes of particular importance in the context of the development of knowledge economy and strengthening of the need to diversify the sources of financing for Ukrainian HEIs. This process is putting forward such objectives for Ukrainian HEIs: export of educational and research services, enrollment of foreign students. In this context the process of internationalization promotes possibility to receive grants for teachers, students, and HEIs themselves through joint granting schemes and development of strategic partnerships.

3. Academic rationale provides possibility to enhance the quality of Ukrainian HE by means of internationalization, which might be achieved by: internationalization of educational programs and courses; stimulation and organizational support for foreign internships of teachers, students, researchers; organization and participation of teachers, students and researchers in international scientific conferences; stimulation and organizational support of scientific publications in international journals and their representation in international science-computer databases; organizational support for carrying out joint scientific researches and educational and research projects with foreign researchers; development of international partnership between HEIs and between scientific communities; creation of international educational alliances. These activities can serve as a pragmatic goal for increasing international competitiveness of Ukrainian HEIs and their international reputation.

4. Cultural rationale is related to the expansion of opportunities for intercultural dialogue, cultural cooperation and partnership, education in the spirit of peace, for- mation of tolerance, etc. Here the study of a foreign language, first of all, English as a language of international communication and academic cooperation, becomes of great importance. But equally important is the ability to best position the traditions, culture and language of their own country. Social justification is related to the fact that students and researchers while in the international environment become less provincial, more open to the perception of the other, more tolerant and able to find understanding that can contribute to the improvement of social climate both in society and in the world.

Taking as the basis for the research the works by $\mathrm{J}$. Knight, to these four rationales the fifth - nationally relevant one - has been added. It means human resource development, strategic alliances for Ukrainian HEIs, state building and socio-cultural development, mutual understanding among different nations; at the institutional level - international branding and profiling, raising the quality of Ukrainian education in line with international revenuegenerating standards, developing strategic alliances and knowledge production [7, p. 25].

Thus, the system of HE in Ukraine can be redefined within the context of the internationalization process be means of the following: deepening, expanding and diversifying contacts with national, regional and global partners; better training of students as national and global citizens and productive members of society; expansion of students' access to educational programs and international mobility schemes; expanding the opportunities for faculty members and researchers to participate in international research activities, in international academic networks, to conduct research on burning international issues, and to use the experience and perspectives of scientists from many parts of the world; increasing institutional efficiency through the enrichment of international experience and partnership; improving of institutional policy, management, service functions through the exchange of experience across national borders; promoting the development of Ukraine at the expense of new financial revenues and multiplication of human, intellectual and innovative capital; contributing to global development and ensuring joint responsibility for it.

Conclusions. Universities have now become key players in the global economy, contributing significantly not only to the knowledge stock of the world, but also to the financial economy of their countries. Different universities will be expected to respond in different ways to globalization trends as much as they are also expected to have different conceptualizations of what it means to internationalize the roles of teaching, research, quality insurance and management. However, a review of the research works on the topic of internationalization in HE suggests that many universities have adopted a two-pronged approach to the internationalization process, encompassing home-based (internationalization at home) and overseasbased (internationalization abroad) activities.

Overall, the system of Ukrainian HE can be redefined within the context of the internationalization process within the five distinct sets of activities (based on the five practical rationales for internationalization outlined above): international student recruitment; student and staff mobility programmes; collaborative teaching programmes (joint degrees), overseas campuses and distance 
learning programmes; collaborative research and enterprise programmes; and curriculum reform programmes. Internationalization for Ukrainian HE system is of significant importance because of the following - people of today live and work in an increasingly interconnected globalized world as professionals, citizens and biological beings, they face a range of situations - challenges and opportunities - that require domestic HE systems and institutions to deliver something more apart from traditional education issues. In case internationalization pro- cess becomes more integrated into Ukrainian HE, the outcomes might be: appreciation and leverage of a multitude of international perspectives; ability to operate appropriately and effectively in an array of contexts, to make sense of world complexity. Thus, internationalization is not a goal itself. It means investment (of money and staff) which in the long run might improve some of the core tasks of Ukrainian HEIs - teaching, research, social engagement, efficiency, effectiveness, quality.

\section{REFERENCES}

1. Altbach P. G. The Internationalization of Higher Education: Motivations and Realities / P. G. Altbach, J. Knight. - Studies in International Education, 2006. - V. 1. - P. 290-305.

2. Beelen J. Redefining Internationalization at Home. - J. Beelen, E. Jones // The European Higher Education Area: Between Critical Reflections and Future Policies, 2015. Springer International. - P. 326.

3. Damme D. Van. Quality Issues in the Internationalization of Higher Education. - Higher Education, 2001. - Vol. 41. - P. $415-441$.

4. Fielden J. Lite Practice of Internationalization: Managing International Activities in UK Universities. - UK Higher Education International Unit, 2008. - P. 67.

5. Goddard S. E. Uncommon Ground: Indivisible Territory and the Politics of Legitimacy. - International Organization, 2006. - Vol. 60. - P. $35-68$.

6. Knight J. Internationalization Re-Modelled: Definition, Approaches, and Rationales. - Journal of Studies in International Education, 2004. - No. 8, (1). - P. 5 - 31.

7. Knight J. Higher Education in Turmoil. The Changing World of Internationalization. - Rotterdam, the Netherlands : Sense Publishers, 2008. - P. 25.

8. Law of Ukraine On Higher Education. - Electronic Access : http://bctdatu.zp.ua/zakon-pro-vishhu-osvitu.

9. Maringe F. Globalization and Internationalization of HE: An International Survey / F. Maringe, J. Foskett. - School of Education : University of Southampton Press, 2009. - P. 136.

10. Monitoring of the Integration of Ukrainian Higher Education System into European Higher Education and Research Area: Analytical Report / Ed. T.V. Finikov, O. I. Sharov. - K. : Tacson, 2014. - 144 p. - P. $130-143$.

11. Teichler U. The Changing Debate on Internationalization of Higher Education. - Higher Education, 2004. - Vol 48. - P. 5 $-26$.

12. Trends in Global Higher Education: Tracking an Academic Revolution / Ph. G. Altbach, L. Reisberg, L. E. Rumbley. United Nations Educational, Scientific and Cultural Organization, 2009. - P. 45.

13. Wit K. de. The Consequences of European Integration for Higher Education. - Higher Education Policy, 2003. - No. 16 (2). - P. $101-178$.

14. Zhyliayev I. B. Higher Education in Ukraine: State and Problems / I. B. Zhyliayev, V. V. Kovtunets, M. V. Syomkin. - K. : Institute of Higher Education of the National Academy of Pedagogical Sciences of Ukraine, 2015. - P. 88.

Переопрделение системы высшего образования в Украине в контексте процесса интернационализации: практическое обоснование

И. В. Мигович

Аннотация. Статья посвящена исследованию процесса интернационализации в высшем образовании. Интернационализация рассматривается как реакция на глобальные процессы трансформации, а также как уникальная возможность для украинской системы высшего образования обеспечить интеграцию в соответствии с европейскими и мировыми тенденциями. На основе исследования теории интернационализации, международного образования, международного рекрутинга и мобильности персонала, вопросов качества и управления в высшем образовании изложен ряд практических обоснований интернационализации высшего образования, применимых в контексте украинской системы высшего образования. На их основе обозначены образовательные результаты интернационализации в украинском высшем образовании.

Ключевые слова: процесс интернационализачии, глобальная система высшего образования, украинская система высшего образования, обоснование интернационализащии. 